\title{
Fake Fragments, Flexible Provenances: Eight Aramaic "Dead Sea Scrolls" from the 21st Century
}

\author{
Årstein Justnes
}

\begin{abstract}
Museums and researchers often describe the origins of a particular object - its provenance, or place of discovery and subsequent chain of ownership - with only a few words and a date. This is a huge problem. The way we present provenance affects our ability to authenticate antiquities, their legal status, the professional ethics tied to them, even their price. We must ask difficult questions about the origins of the objects we study. ${ }^{1}$

ROBERTA MAZZA
\end{abstract}

How are things authenticated today? Basically, if the Kando family says, "this comes from Cave 4," that's about the best you can do for provenance. [...] That's just the way it's been from the beginning. ${ }^{2}$

WESton W. FIELDS, Executive Director of the Dead Sea Scrolls Foundation

The eight Aramaic fragments discussed in this article form part of a bigger story. Since 2002 more than 75 "new" Dead Sea Scroll fragments have surfaced on the antiquities market. ${ }^{3}$ Recently, we have seen a growing consensus, especially

1 Roberta Mazza, "The Illegal Papyrus Trade and What Scholars Can Do to Stop It," Hyperallergic, 1 March 2018, https://hyperallergic.com/429653/the-illegal-papyrus-trade -and-what-scholars-can-do-to-stop-it/.

2 Weston W. Fields, "Dead Sea Scrolls: Significance of the Latest Developments," The Lanier Library Lecture Series, 16 April 2011, https://www.youtube.com/watch?v=cOcNhHsGKu4. Quoted from the Q \& A session, https://www.youtube.com/watch?v=9qgLWNRtL5Q.

3 For a comprehensive list of all the acquisitions known to us after 2002, see Årstein Justnes and Ludvik A. Kjeldsberg, "The Post-2002 Dead Sea Scrolls Fragments: A Tentative Timeline

(C) ÅRSTEIN JUSTNES, 2020 | DOI:10.1163/9789004413733_014

This is an open access chapter distributed under the terms of the CC-BY-NC 4.0 License 
among younger scholars, that a majority of these are modern forgeries. ${ }^{4}$ The issue of provenance, however, still does not seem to interest Qumran scholars much. ${ }^{5}$ Provenance research has traditionally been a neglected element in Qumran studies. Since the majority of the "original" Dead Sea Scrolls were nonprovenanced, strictly speaking, the guild has had a quite relaxed attitude towards non-provenanced material. Most scholars have until very recently treated the new fragments as Dead Sea Scroll fragments by default. ${ }^{6}$

of Acquisitions," The Lying Pen of Scribes: Manuscript Forgeries and Counterfeiting Scripture in the Twenty-First Century, 7 June 2018, https://lyingpen.com/.

4 See first and foremost Kipp Davis, Ira Rabin, Ines Feldman, Myriam Krutzsch, Hasia Rimon, Årstein Justnes, Torleif Elgvin, and Michael Langlois, "Nine Dubious 'Dead Sea Scrolls' Fragments from the Twenty-First Century," DSD 24 (2017): 189-228, and Kipp Davis, "Caves of Dispute: Patterns of Correspondence and Suspicion in the Post-2002 'Dead Sea Scrolls' Fragments," $D S D 24$ (2017): 229-70. In the former article four of the eight Aramaic post2002 fragments are dealt with at length, and it is argued that they are modern forgeries (see also Michael Langlois, "Nine Dubious 'Dead Sea Scrolls' Fragments from the Twenty-First Century," The Blog of Michael Langlois, 8 October 2017, https://michaellanglois.fr/en/publications/neuf-fragments-de-manuscrits-de-la-mer-morte-douteux-apparus-au-xxie-siecle). See also Årstein Justnes and Torleif Elgvin, "A Private Part of Enoch: A Forged Fragment of 1 Enoch 8:4-9:3," in Wisdom Poured Out Like Water: Studies on Jewish and Christian Antiquity in Honor of Gabriele Boccaccini, ed. J. Harold Ellens, Isaac W. Oliver, Jason von Ehrenkrook, James Waddel, and Jason M. Zurawski, DCLS 38 (Berlin and Boston: Walter de Gruyter, 2018), 195-203; the recent lecture by Eibert J. C. Tigchelaar, "Beautiful Bookhands and Careless Characters: An Alternative Approach to the Dead Sea Scrolls," The 8th Annual Rabbi Tann Memorial Lecture, University of Birmingham, 24 January 2018, https://www.youtube.com/ watch?time_continue $=5 \& \mathrm{v}=$ thB2tH1kwtU; and the lectures from 2017 by Kipp Davis, Torleif Elgvin, Michael Langlois, Ira Rabin, and Årstein Justnes posted on the Lying Pen blog (Årstein Justnes and Ludvik A. Kjeldsberg, "Post-2002 Dead Sea Scrolls-like Fragments Online: A [Really Exhausting] Guide for the Perplexed," The Lying Pen of Scribes: Manuscript Forgeries and Counterfeiting Scripture in the Twenty-First Century, 26 June 2018, https://lyingpen.com/).

5 In both the Schøyen volume (Torleif Elgvin, Kipp Davis, and Michael Langlois, eds., Gleanings from the Caves: Dead Sea Scrolls and Artefacts from The Schøyen Collection, LSTS 71 [London: T\&T Clark, 2016]) and the Museum of the Bible volume (Emanuel Tov, Kipp Davis, and Robert Duke, eds., Dead Sea Scrolls Fragments in the Museum Collection, Publications of Museum of the Bible 1 [Leiden: Brill, 2016]) there is a fundamental lack of critical interest in the issue of provenance. This is addressed in book reviews by Molly M. Zahn (Review of Gleanings from the Caves: Dead Sea Scrolls and Artefacts from the Schøyen Collection, ed. Torleif Elgvin, Kipp Davis, and Michael Langlois, DSD 24 [2017]: 307-9) and Årstein Justnes (Review of Dead Sea Scrolls Fragments in the Museum Collection, ed. Emanuel Tov, Kipp Davis, and Robert Duke, $D S D$ [2017]): 310-12), cf. for instance Zahn on p. 308: “[...] there is [...] [a] thought-provoking, indeed troubling issue that looms large precisely because of the relative lack of explicit attention it receives in the volume: the issue of provenance." See, however, the recent article by Dennis Mizzi and Jodi Magness, "Provenance vs. Authenticity: An Archaeological Perspective on the Post-2002 'Dead Sea Scrolls-Like' Fragments” in DSD 26 (2019): 135-69.

6 See Esther Eshel and Hanan Eshel, "A New Fragment of the Book of the Watchers from Qumran (XQpapEnoch)," Tarbiz 73 (2004): 171-79; idem, "New Fragments from Qumran: 4QGenf, 4QIsa ${ }^{\text {b }}$ 4Q226, 8QGen, and XQpapEnoch," DSD 12 (2005): 134-57; Michaela 
All the eight fragments in this article are non-provenanced and undocumented. From what I know, there are no trustworthy lists of previous owners for any of them, only vague stories and/or allusive lists, whose main function probably is to "prove" that the fragments were taken out of Israel before 1970 or 1978 (thereby implying that their removal and exportation predatedand therefore have not contravened-the 1970 Convention on the Means of Prohibiting and Preventing the Illicit Import, Export and Transfer of Ownership of Cultural Property by UNESCO or the 1978 Antiquities Law of the State of Israel). ${ }^{7}$

In what follows, I will try to place these eight fragments in a chronology and analyze the information that I have been able to gather about their origins and provenance. I will not discuss the issues of authenticity or forgery thoroughly, as I regard it as already settled that all the fragments are modern forgeries. I also fully agree with Mizzi and Magness, "Provenance vs. Authenticity," that

Hallermayer and Torleif Elgvin, "Schøyen ms. 5234: Ein neues Tobit-Fragment vom Toten Meer," RevQ 22/87 (2006): 451-61; Esther Eshel and Hanan Eshel, "A Preliminary Report on Seven New Fragments from Qumran," Meghillot 5-6 (2007): 271-78; James H. Charlesworth, "What Is a Variant? Announcing a Dead Sea Scrolls Fragment of Deuteronomy," Maarav 16 (2009): 201-12; Émile Puech, "Un nouveau fragment 7a de 4QGn-Exa $=4$ QGen-Ex 1 et quelques nouvelles lectures et identifications du manuscrit 4Q1," RevQ 25/97 (2011): 103-11; Emanuel Tov, "New Fragments of Amos," DSD 21 (2014):3-13; Elgvin et al., eds., Gleanings from the Caves, and Tov et al., eds., Dead Sea Scrolls Fragments in the Museum Collection.

7 Cf. Daniel Estrin, "Dead Sea Scroll fragments to hit the auction block," Times of Israel, 25 May 2013, http://www.timesofisrael.com/dead-sea-scroll-fragments-to-hit-the-auction-block:

Nearly 70 years after the discovery of the world's oldest biblical manuscripts, the Palestinian family who originally sold them to scholars and institutions is now quietly marketing the leftovers-fragments the family says it has kept in a Swiss safe deposit box all these years.[...]

[...] Kando held much more than he surrendered to Israel. William, his son, said his father had fragments tucked away which he eventually transferred to Switzerland in the mid-196os.

In 1993, just as scholars finally began publishing research of Israeli-held scrolls, and the world was abuzz with Dead Sea Scroll fever, Kando died, bequeathing his secret collection of fragments to his sons.

It was the perfect time to sell.[...]

[...] Kando said his father transferred fragments to Switzerland in the mid-196osbefore Israel passed its 1978 law preventing the unauthorized removal of antiquities from the country.

See also James H. Charlesworth, "The Discovery of an Unknown Dead Sea Scroll: The Original Text of Deuteronomy 27?" OWU Magazine, Summer 2012, https://web.archive.org/ web/20140226221353/http://blogs.owu.edu/magazine/the-discovery-of-an-unknown-dead -sea-scroll-the-original-text-of-deuteronomy-27/, and Fields, "Significance."

Concerning the role of the scholars in this saga, see Årstein Justnes and Josephine M. Rasmussen, "Soli Deo Gloria? The Scholars, the Market, and the Dubious Post-2002 Dead Sea Scrolls-like Fragments," The Bible and Interpretation, 11 November 2017, http://www .bibleinterp.com/. 
The Aramaic post-2002 fragments at a glance

\begin{tabular}{|c|c|c|c|c|c|c|}
\hline $\begin{array}{l}\text { Known } \\
\text { since }\end{array}$ & Content & $\begin{array}{l}\text { Collection } \\
\text { number }\end{array}$ & $\begin{array}{l}\text { Dss F.no } \\
\text { Dss F.name } \\
\text { [designation] }\end{array}$ & $\begin{array}{l}\text { Tov's } 2010 \\
\text { List }\end{array}$ & $\begin{array}{l}\text { Lines, } \\
\text { measurements, } \\
\text { and material }\end{array}$ & $\begin{array}{l}\text { Dealer(s) } \\
>\text { collection(s) }\end{array}$ \\
\hline 2003 & $\begin{array}{l}\text { Tob } \\
14: 3-4\end{array}$ & MS 5234 & $\begin{array}{l}\text { DSS F.123 } \\
\text { DSs F.Tob1 }\end{array}$ & $\begin{array}{l}\text { 4Q196* } \\
\text { papTob }^{*} \text { ar }\end{array}$ & $\begin{array}{l}7 \text { lines } \\
6.8 \times 2.2 \mathrm{~cm} \\
\text { papyrus }\end{array}$ & $\begin{array}{l}\text { William Kando } \\
\text { > Schøyen Collection } \\
\left(\text { September? 2003) }{ }^{\dagger}\right.\end{array}$ \\
\hline 2003 & Tob 7:1-3 & & [XpapTobit ar] & & $\begin{array}{l}4 \text { lines } \\
\text { papyrus }\end{array}$ & William Kando \\
\hline 2004 & $\begin{array}{l}1 \text { En. } \\
8: 4-9: 3\end{array}$ & $\begin{array}{l}\text { MS } \\
4612 / 12\end{array}$ & $\begin{array}{l}\text { DSS F.125 } \\
\text { DSs F.En2 }\end{array}$ & $\begin{array}{l}\text { X26 } 6^{\ddagger} \\
\text {XpapEn }^{\mathrm{a}}\end{array}$ & $\begin{array}{l}5 \text { lines } \\
5.8 \times 4.3 \mathrm{~cm} \\
\text { papyrus }\end{array}$ & $\begin{array}{l}\text { William Kando (Bruce } \\
\text { Ferrini } \rightarrow \text { Esther \& } \\
\text { Hanan Eshel) } \\
>\text { Schøyen Collection } \\
\text { (April 2009) }\end{array}$ \\
\hline 2008 & $\begin{array}{l}1 \text { En. } \\
7: 1-5\end{array}$ & MS 4612/8 & $\begin{array}{l}\text { DSS F.124 } \\
\text { DSS F.En1 }\end{array}$ & $\begin{array}{l}\mathrm{X} 27^{\ddagger} \\
\mathrm{XEn}{ }^{\mathrm{b}} \text { ar }\end{array}$ & $\begin{array}{l}5 \text { lines } \\
3.8 \times 5 \cdot 3 \mathrm{~cm} \\
\text { parchment }\end{array}$ & $\begin{array}{l}\text { William Kando } \\
\text { > Schøyen Collection } \\
\text { (January or April 2009) }\end{array}$ \\
\hline 2008 & $\begin{array}{l}\text { Dan } \\
5: 13^{-16}\end{array}$ & $\mathrm{APU}_{5}$ & $\begin{array}{l}\text { DSS F. } 155 \\
\text { DSs F.Dan1 }\end{array}$ & & $\begin{array}{l}5 \text { lines } \\
\text { parchment }\end{array}$ & $\begin{array}{l}\text { Lee Biondi } \\
>\text { Azusa Pacific } \\
\text { University } \\
(\text { August 2009) })^{\#}\end{array}$ \\
\hline 2008 & $\begin{array}{l}\text { Dan } \\
6: 22-24\end{array}$ & & $\begin{array}{l}\text { Dss F.166 } \\
\text { Dss F.Dan2 }\end{array}$ & $\begin{array}{l}\text { X24 } 4^{* *} \\
\text { XpapDan }\end{array}$ & $\begin{array}{l}4 \text { lines } \\
2.5 \times 6 \mathrm{~cm} \\
\text { papyrus }\end{array}$ & $\begin{array}{l}\text { William Kando } \\
>\text { South-western } \\
\text { Baptist Theological } \\
\text { Seminary (19[?] } \\
\text { January 2010) }\end{array}$ \\
\hline 2009 & $\begin{array}{l}1 \mathrm{En} . \\
106: 19- \\
107: 1\end{array}$ & $\operatorname{MS~} 4612 / 6$ & $\begin{array}{l}\text { DSs F.126 } \\
\text { Dss F.En3 }\end{array}$ & $\begin{array}{l}\mathrm{X}_{2} 8^{\ddagger} \\
\mathrm{XEn}^{\mathrm{c}} \text { ar }\end{array}$ & $\begin{array}{l}3 \text { lines } \\
2.9 \times 8.3 \mathrm{~cm} \\
\text { papyrus }\end{array}$ & $\begin{array}{l}\text { William Kando } \\
\text { > Schøyen Collection } \\
\text { (April-[?] 2009) }\end{array}$ \\
\hline 2010 & $\begin{array}{l}\text { Dan } \\
7: 18-19\end{array}$ & & $\begin{array}{l}\text { Dss F.167 } \\
\text { Dss F.Dan3 }\end{array}$ & & $\begin{array}{l}3 \text { lines } \\
1.2 \times 1.6 \mathrm{~cm} \\
\text { papyrus }\end{array}$ & $\begin{array}{l}\text { William Kando } \\
\text { > Southwestern } \\
\text { Baptist Theological } \\
\text { Seminary (19[?] } \\
\text { January 2010) }\end{array}$ \\
\hline
\end{tabular}

* $\quad$ Emanuel Tov, Revised List of Texts from the Judaean Desert (Leiden: Brill, 2010), 35.

$\dagger \quad$ Personal information from Martin Schøyen to Torleif Elgvin.

$\ddagger \quad$ Tov, Revised List, 110 .

\# Azusa Pacific's Dead Sea Scrolls and Biblical Artifacts Exhibition Opens May 21: News Release," Azusa Pacific University, 11 May 2010, https://www.apu.edu/media/news/ release $/ 15664 /$.

** Tov, Revised List, 110 and 129 . 
considerations of provenance should take priority over authenticity. Because of the space limitations, let me start with a brief overview of the fragments under scrutiny.

It should be noted that six out of the eight fragments are written on papyrus, and that seven of them are between only 3 and 5 lines. With the possible exception of Dan 5:13-16, they all seem to come from the Bethlehem antiquities dealer William Kando, son of the legendary Khalil Iskander Shahin, or "Kando."

In the autumn of 2002 William Kando started to contact American antiquities dealers, and later also the Norwegian collector Martin Schøyen. ${ }^{8}$ The first five fragments that William Kando offered for sale were all in Hebrew and ended up after some time in the Ink \& Blood collection. ${ }^{9}$ The first Aramaic fragment landed in Norway in the autumn of 2003.

\title{
2 Tob 14:3-4 (DSs F.123, DSs F.Tob1) and Tob 7:1-3 (XpapTobit ar)
}

Between June 2003 and June 2004 Schøyen bought several fragments from William Kando, and among them an Aramaic Tobit fragment. ${ }^{10}$ The fragment first appeared on Schøyen's webpage sometime between 12 December 2003 and 11 March 2004, but was—strangely and surprisingly—presented as Tob 7:1-3:

\author{
MS 5234 \\ TOBIT DEAD SEA SCROLL \\ BIBLE: TOBIT 7:1-3 [captured 11 March 2004]
}

MS in Aramaic on papyrus, Qumran, ca. 1-68 AD, 1 fragment, 6,8 × 2,1 $\mathrm{cm}$, part of right side of a column, $(5,9 \times 1,6 \mathrm{~cm})$, part of 7 lines in a late Herodian Hebrew book script.

8 In his personal reflection in Gleanings from the Caves, Schøyen takes credit for having opened the market for the post-2002 fragments. See Martin Schøyen, "Acquisition and Ownership History: A Personal Reflection," in Gleanings from the Caves: Dead Sea Scrolls and Artefacts from The Schøyen Collection, ed. Torleif Elgvin, Kipp Davis, and Michael Langlois, LSTS 71 (London: T\&T Clark, 2016), 27-31 (30), and Justnes and Rasmussen, "Soli Deo Gloria?" 3.

9 See https://inkandblood.com/index.php/project/dead-sea-scrolls/.

10 According to Elgvin, Schøyen has recently indicated the following acquisition dates for these fragments: Deut 6:1-2 (MS 5214; DDS F.108), June 2003; 2 Sam 20 (MS 5233/1; DSS F.114) and Tobit (MS 5234; DSS F.123), September 2003; and Ps 78:12/119:19/141:7 (MS 5095/5; DSS F.118), June 2004. In all probability, Exodus (4612/2) and Eschat (4612/3) were also acquired in the same period. 
Context: The only fragment surviving from this Dead Sea Scroll. Only 4Qpap.TobitAar=4Q196 (ca. 50 BC) and 4QTobitBar=4Q197 (са. 30 вС$25 \mathrm{AD}$ ) have parts of the same text, published in DJD XIX, pl. I-VII.

Provenance: 1. Community of the Essenes, Qumran (ca. 1-68 AD); 2. Qumran Cave 4 or 11 (68-1956); 3. Khalil Iskander Shakin ("Kando"), Bethlehem (1956-1972); 4. Private collection, Switzerland (1972-2003).

Commentary: Part of this MS is not on 4Q196 and 4Q197, thus being the earliest witness to this part of the Bible. Tobit (or Tobias) was written in the $5^{\text {th }}$ or 4 th c. BC, and is an apocryphal book in the Hebrew Bible, but part of the Septuagint. The present text is first part of how Raguel gave his daughter Sarah as bride to Tobias, son of Tobit, according to the ordinance in the Law of Moses. ${ }^{11}$

Schøyen is here confusing the Tob 14:3-4 fragment (7 lines) with the Tob 7:1-3 fragment (4 lines). So, while the physical description of the fragment on his site matches Tob 14:3-4, the paraphrase of the content ("Commentary") fits with Tob 7:1-3.

Somewhere between 11 March and 26 April, the date, the palaeographical information, and the identification changed significantly (I have indicated the changes by italics below):

BIBLE: TOBIT 7:1-3 [captured 26 April 2004]

MS in Aramaic on papyrus, Qumran, $c a .50 B C, 1$ fragment, 6,8 $\times 2,1 \mathrm{~cm}$, part of right side of a column, $(5,9 \times 1,6 \mathrm{~cm})$, part of 7 lines in a late semiformal Hasmonaean Hebrew book script.[...]

Context: Part of fragment 14 of 4Qpap.TobitAar $=4$ Q196 (са. 50 вС). 4QTobitBar=4Q197 (ca. $30 \mathrm{BC}-25 \mathrm{AD}$ ) have parts of the same text, both published in DJD XIX, pl. I-VII.

Provenance: 1. Community of the Essenes, Qumran (ca 50 BC-68 AD); 2. Qumran Cave 4 (68-1956); 3. Khalil Iskander Shakin ("Kando"), Bethlehem (1956-1972); 4. Private collection, Switzerland (1972-2003).

Commentary: This $M S$ with the other fragments of $4 Q_{19} 6$, is the earliest witness to this part of the Bible. Tobit (or Tobias) was written in the $5^{\text {th }}$ or 
4th c. BC, and is an apochryphal book in the Hebrew Bible, but part of the Septuagint. The present text is first part of how Raguel gave his daughter Sarah as bride to Tobias, son of Tobit, according to the ordinance in the Law of Moses. The allocation of this MS to 4Q196 was kindly communicated by Florentino Garcia Martinez. ${ }^{12}$

Two short months later, further corrections were added on the website: The fragment was linked to the correct passage, the fragment number was modified, and the paraphrase changed to correspond with Tob 14:3-4. But, most notably, the last point in list of previous owners (cf. Provenance) was changed: The private collection in Switzerland was replaced by a certain "American priest, later serving in Switzerland (1972-95)." This change ends "the chain of owners" already in 1995 implying that the fragment was acquired by the Schøyen Collection as early as in the mid-nineties. ${ }^{13}$

\section{BIBLE: TOBIT 14:4-6 [captured 17 June 2004]}

MS in Aramaic on papyrus, Qumran, ca. $5^{\circ} \mathrm{BC}, 1$ fragment, 6,8 $\times 2,1 \mathrm{~cm}$, part of right side of a column, $(5,9 \times 1,6 \mathrm{~cm})$, part of 7 lines in a late semiformal Hasmonaean Hebrew book script.[...]

Context: Part of the column next to fragment 8 of 4 Qpap.TobitAar $=4$ Q196 (ca. 50 BC). 4 QTobitCar $=4 Q 198$ ( ca. $50 \mathrm{BC}$ ) has parts of the same text, both published in DJD XIX, pl. I-VIII.

Provenance: 1. Community of the Essenes, Qumran (ca 50 BC-68 AD); 2. Qumran Cave 4(68-1956); 3. Khalil Iskander Shahin ("Kando"), Bethlehem (1956-1972); 4. American priest, later serving in Switzerland (1972-1995).

Commentary: This MS with the other fragments of $4 \mathrm{Q} 196$, is the earliest witness to this part of the Bible. Tobit (or Tobias) was written in the $5^{\text {th }}$ or 4th c. BC, and is an apochryphal book in the Hebrew Bible, but part of the Septuagint. The present text is Tobit's instructions given when he was at the point of death in Nineveh, to his son Tobias and his seven sons, ordering them to hurry away to Media, as Assyria and Babylonia will not be

12 https://web.archive.org/web/20040426174053/http://www.nb.no:8o/baser/schoyen/ $5 / 5.9 /$.

13 This change may have been motivated by Norway's ratification of the UNIDROIT Convention on Stolen or Illegally Exported Cultural Objects (1995) in 2001. 
safe according to the prophets' of Israel. The present Aramaic text is rather different from the Septuagint, and shorter ${ }^{14}$

The changing identity of the Schøyen Tobit fragment is worth noticing. It shows that already in 2003 there were two Tobit fragments in the game. Schøyen, however, only bought one of them, namely DSs F.123 (= Tob 14:3-4). Furthermore, my review above also shows that the Schøyen Collection during the first half of 2004 changed provenance information for this fragment twice. ${ }^{15}$

The Schøyen fragment was exhibited in Oslo during the Nordic Network in Qumran Studies Symposium 3-5 June 2004. The first scholarly mention of it was made in 2005 by Edward M. Cook on his blog, ${ }^{16}$ where he even made use of the fragment to reconstruct "the Aramaic Urtext of the Greek Tobit in the Sinaitic Recension."17 The fragment was subsequently published by Michaela Hallermayer and Torleif Elgvin in 2006 as part of 4Q196 (4QpapToba ar). ${ }^{18}$ This identification, first suggested by Florentino García Martínez on the basis of a photograph on the Schøyen Collection website, however, turned out to be wrong.

From 2012 onwards, several scholars-obviously informed by Elgvin's preliminary edition written for the Schøyen volume-briefly mention the fragment in single footnotes: Hanna Tervanotko refers to a "pre-publication version" of "Torleif Elgvin, '4QpapTobit ${ }^{\mathrm{a}}$ frg 18 (Tobit 14:3-4), MS 5234', in Gleanings from the Caves. Dead Sea Scrolls and Artifacts from The Schøyen Collection (ed.

14 https://web.archive.org/web/20040617102110/http://www.nb.no:8o/baser/schoyen/5/5.9/. This version is basically accepted and presupposed (but even further developed) in Hallermayer and Elgvin, "Schøyen MS. 5234," 452: "Bevor dieses Fragment im Januar 2001 durch die Schøyen Collection erworben wurde, war es von 1956-1972 zunächst im Besitz von Khalil Iskander Shahin (“Kando"), Betlehem, von 1972-1995 dann im Besitz eines nicht näher genannten amerikanischen Priesters, der später in der Schweiz tätig war, von 1995-2001 schließlich im Besitz der Kando-Familie und wurde in Zürich aufbewahrt.”

15 The misidentification is also reflected in Eshel and Eshel, "New Fragments from Qumran," 146, n. 29: "It has recently been revealed that there is a seven-line Aramaic papyrus in the Schøyen Collection that preserves portions of Tobit 7:1-3. This fragment [...] is the first to be published from another copy of Tobit."

16 Edward M. Cook, "A Lost Scrap of Tobit from the Schoyen Collection," Ralph the Sacred River, 9 December 2005, http://ralphriver.blogspot.dk/2005/12/lost-scrap-of-tobit-from -schoyen.html.

17 Edward M. Cook, "Reconstruction of the Aramaic Urtext of the Greek Tobit in the Sinaitic Recension,” https://web.archive.org/web/20060211013840/http://homepage.mac.com/ed cook/TobitUrtxt.pdf.

18 Hallermayer and Elgvin, "Schøyen MS. 5234," 451-61. 
Torleif Elgvin; T\&T Clark, 2011), forthcoming."19 In 2014 it is mentioned by Tawny L. Holm, but now as a fragment of a new composition, 4Q196a:

Note also a fragment of Tobit 14:4-6 in the Schøyen private collection, MS 5234, which used to be thought of as part of 4Q196, but has now been classified as a "new papyrus copy" (4Q196a) of Tobit; see http://torlei felgvin.wordpress.com/english/, accessed $28 \mathrm{Feb} .2013 .{ }^{20}$

In her thorough 2017 article "Tobit and the Qumran Aramaic Texts," Devorah Dimant also pays the fragment a short visit:

Following Józef Milik, Fitzmyer was aware of only four Aramaic manuscripts, but in 2006 two scholars published a photograph and decipherment of a small papyrus fragment from Qumran containing Tob 14:3-4 that was unknown to Fitzmyer, which is now part of the Schøyen Collection. The authors considered it a fragment of the already known Qumran papyrus copy of Tobit, 4Q196, published by Fitzmyer.[...] However, upon inspection of the photograph of the fragment forwarded to me by Prof. Elgvin, [...] it became clear that the fragment comes from a different papyrus manuscript.[...] Stuart Weeks notes that another fragment from the same sixth manuscript may be found in private hands. [...] Thus, the Qumran library held six copies of Tobit, five in Aramaic and one in the Hebrew. ${ }^{21}$

These quoted pieces illustrate the great willingness of Dead Sea Scrolls scholars to let new, non-provenanced material into the dataset. It is particularly

19 Hanna Tervanotko, "You Shall See': Rebekah's Farewell Address in $4 \mathrm{Q}_{3} 643$ ii 1-6," in The Hebrew Bible in Light of the Dead Sea Scrolls, ed. Nóra Dávid et al., F RLANT 239 (Göttingen: Vandenhoeck \& Ruprecht, 2012), 413-26 (425, n. 47).

20 Tawny L. Holm, "Memories of Sennacherib in Aramaic Tradition," in Sennacherib at the Gates ofJerusalem (701 B.C.E.): Story, History and Historiography, ed. Isaac Kalimi and Seth Richardson, CHANE 71 (Leiden: Brill, 2014), 295-323 (309, n. 56). It is also mentioned in a single sentence by George J. Brooke. See his "Dead Sea Scrolls Scholarship in the United Kingdom," in The Dead Sea Scrolls in Scholarly Perspective: A History of Research, ed. Devorah Dimant, STDJ 99 (Leiden: Brill, 2012), 449-86 (481, n. 159). Loren Stuckenbruck and Stuart Weeks, "Tobit," in T\&T Clark Companion to the Septuagint, ed. James K. Aitken (London: Bloomsbury, 2015), 237-6o (237, n. 2), say that the "fragment belongs to the same manuscript as 4Q196." In another formulation on p. 238, probably referring to the same fragment, they mention "some additional material initially thought to be from 4Q196 and published as such, [...] now believed to represent a fifth Aramaic manuscript (4Q196a)." Devorah Dimant, "Tobit and the Qumran Aramaic Texts," in From Enoch to Tobit: Collected Studies in Ancient Jewish Literature, ed. Devorah Dimant, FAT 114 (Tübingen: Mohr Siebeck, 2017), 173-91 (175). 
with this fragment in mind that Dimant summarizes the number of Tobit manuscripts as follows: "[...] the Qumran library yielded six copies of the book, five in Aramaic (4Q196-4Q199, XQTob) and one in Hebrew (4Q200)."22 According to Dimant, XQTob consists of two fragments, the Schøyen Tobit and the fragment mentioned by Weeks. Dimant includes the last fragment into the dataset purely on the basis of a secondary reference, i.e. Weeks quoting from a private conversation with Eibert Tigchelaar. ${ }^{23}$

After it became apparent that the fragment was a fake, ${ }^{24}$ the Schøyen Collection removed the fragment from its webpage. It was also removed from the Schøyen volume.

Tobit 7:1-3 is a twin to the Schøyen Tobit, and the fragment was at one point also offered for sale to Schøyen (cf. the confusion about this fragment above). ${ }^{25}$ According to Elgvin, Dimant intended to publish it in Revue de Qumran, but it has still not been published. ${ }^{26}$ However, in her 2017 book From Enoch to Tobit, Dimant barely seems aware of the fragment (see above).

The two Tobit papyri dealt with in this part seem to have been written by the same hand, inviting the assumption that both derive from the same scroll-a conclusion reached independently by Elgvin and Dimant (before Elgvin ended up classifying both as forgeries; cf. above).

Interestingly, the first post-2002 fragment that was published in a scholarly journal was an Aramaic fragment, 1 En. 8:4-9:3. By their own account, Hanan and Esther Eshel were invited in September 2003 to serve as academic advisors for an exhibition entitled "From the Dead Sea Scrolls to the Forbidden Book",

22 Dimant, "Tobit," 175. As is seen from the quote, she builds here on Stuart Weeks ("Restoring the Greek Tobit," JSJ 44 [2013]: 1-15 [3]) who speaks about "the discovery of at least five fragmentary Tobit manuscripts at Qumran."

23 See Weeks, "Restoring," 3, n. 6: "Schøyen MS 5234, previously identified as a fragment of 4Q196, actually appears to affirm the existence of an additional Aramaic manuscript; I understand from Eibert Tigchelaar that a further, unpublished fragment of that same manuscript exists in another collection."

24 On this aspect of the story, see Davis et al., "Nine Dubious," 220-21.

25 It is interesting to note that Peter Flint (The Dead Sea Scrolls [Nashville: Abingdon, 2013], 10) even wrote that Schøyen purchased two Tobit fragments between 2000 and 2005.

26 A picture of the fragment was published in the Norwegian newspaper Vart Land in the wake of the "Tracing and Facing the Possibility of Forgeries" session at ISBL in Berlin, 22 August 2017. See Geir Ove Fonn, "Dødehavsruller er lukrativ svindelindustri," Vårt Land, 16 August 2017, https://www.vl.no/nyhet/dodehavsruller-er -lukrativ-svindelindustri-1.1013905?paywall=true. 
first held in Dallas, Texas. ${ }^{27}$ This appointment seems to have given them access to several new "Dead Sea Scrolls" fragments, also the new piece of Enoch:

In March 2004 we received for publication a photograph of a fragmentary papyrus preserving five lines identifiable as the end of $1 \mathrm{En} .8$ and the beginning of 1 En. 9 (8:4-9:3). Though undoubtedly found at Qumran, as we cannot identify the cave, we suggest labeling this fragment XQpapEnoch. ${ }^{28}$

In a footnote on the same page they "thank Bruce Ferrini of Bath, Ohio for providing a photograph of this fragment and for granting [...] [them] permission to publish it." ${ }^{29}$ The Eshels also got permission to publish the five Hebrew Dead Sea Scroll fragments in the exhibition.

The Eshels worked on the fragments at remarkable speed, and submitted their article to Dead Sea Discoveries early in May 2004. ${ }^{30}$ It appeared the following year. ${ }^{31}$ The Enoch fragment was first published in Hebrew (Tarbiz) in 2004. ${ }^{32}$ It was discussed on 11 October 2004 at the University of Michigan by a panel composed of Profs. Gabriele Boccaccini, James C. VanderKam, Esther Eshel, and Hanan Eshel, at the SBL Annual Meeting in November 2004 in San Antonio, and at the Third Meeting of the Enoch Seminar (Camaldoli, Italy, 6-10 June, 2005).

In November 2004 James R. Davila gave the following report from the SBL meeting on PaleoJudaica.com:

Yesterday evening after the Qumran session, Esther and Hanan Eshel gave an impromptu presentation on the new 1 Enoch fragment, whose story broke on PaleoJudaica some time ago. They are calling it XQpapEnoch,

27 Eshel and Eshel, "New Fragments from Qumran," 134. See also Lee Biondi, From the Dead Sea Scrolls to the Forbidden Book: A History of the Bible (Dallas, TX, 2003).

28 Eshel and Eshel, "New Fragments from Qumran," 146. See also Eshel and Eshel, "A New Fragment of the Book of the Watchers," v.

29 Eshel and Eshel, "New Fragments from Qumran," 146, n. 27. See also pp. 134-35, n. 3: "We received the first five fragments at Dallas; the sixth fragment (XQpapEnoch) was given to us in March 2004, when the exhibition was in Akron, Ohio."

30 James R. Davila, "More 1 Enoch from the Qumran Library," PaleoJudaica.com, 10 October 2004, http://paleojudaica.blogspot.no/2004_10_10_archive.html\#109782863646134864.

31 In 2007 the Eshels published seven further fragments (six texts) mainly on the basis of pictures from exhibition catalogues ("A Preliminary Report on Seven New Fragments from Qumran," Meghillot 5-6 [2007], 271-78). Following basically the same approach as in the $D S D$ article two years earlier, they ascribed all the fragments to previously published scrolls: Exod 3:13-15 and 5:9-14 were ascribed to 4QExodc, Deut 19:13-15 to 4QDeut ${ }^{\mathrm{f}}$, Jer 24:6-7 to 4 QJerc , two pieces with text from Ps 11:1-4 to $11 \mathrm{QPs}^{\mathrm{c}}$, and a fragment identified with 4 QInstruction to $4 \mathrm{Q} 416$ (4QInstr ${ }^{\mathrm{b}}$ ). 
since they are confident it comes from a Qumran cave, but they don't know which one, and (unusually for a Qumran scroll and uniquely for a Qumran Enoch manuscript) it's written on papyrus rather than leather. It contains the damaged Aramaic text of 1 Enoch 8:4-9:3, a passage that tells how the archangels looked down from heaven on the corruption of the earth before the Flood, and it allows us to correct one of Milik's reconstructions since the word in question survives on this papyrus. The correct reading or something very close to it was conjectured by Loren Stuckenbruck [...] some time ago, before this fragment was discovered. (Well done, Loren.)

The fragment belongs to the Kando family.[...] The Enoch papyrus is one of 12 unpublished fragments owned by them. The Eshels have seen infra-red photos of 6 of these. Five are biblical fragments from three already known manuscripts: 4 QIsac ${ }^{c}, 4 Q G e n$, and $8 Q$ Gen. The other six look like "black corn flakes" and are now on tour in the USA in the From the Dead Sea Scrolls to the Forbidden Book exhibition. The Eshels haven't seen the fragment in person yet but they are confident enough of its authenticity to publish it now.[...].

There are also rumors that another fragment of the same manuscript exists. ${ }^{33}$

As reflected in this blog post, the Enoch fragment immediately rose to prominence, and was used to correct Milik's celebrated edition of $4 \mathrm{QEn}^{\mathrm{a}}(4 \mathrm{Q} 201)$ from $1976 .{ }^{34}$ Strikingly, the tiny fragment had allegedly managed to preserve a reading cautiously suggested for 201 iv 8 by Stuckenbruck only three years earlier. ${ }^{35}$

33 James R. Davila, "News on the New 1 Enoch Fragment," PaleoJudaica.com, 22 November 2004, http://paleojudaica.blogspot.no/2004/11/news-on-new-1-enoch-fragment-yesterday .html.

34 Eshel and Eshel, "A New Fragment of the Book of the Watchers," v: "The publication of this new fragment of 1 Enoch is important not only as a witness to the existence of another copy in addition to the eleven known Qumran manuscripts of 1 Enoch, but also because of its contribution to the reconstruction of two Cave 4 Aramaic manuscripts. [...] Despite their poor preservation, it is possible to read and reconstruct in the three Aramaic witnesses a similar, if not identical, text.[...] If our suggested reconstruction of this new fragment is correct, it apparently preserves part of an extensive description of the harm the Watchers inflicted on humanity." See also Eshel and Eshel, "New Fragments from Qumran," 156, and Hanan Eshel, "Gleaning of Scrolls from the Judean Desert," in The Dead Sea Scrolls: Texts and Context, ed. Charlotte Hempel, STDJ 90 (Leiden: Brill, 2010), 49-87 (74): "The text here is important, because it makes it possible to correct a number of reconstructions proposed by Joseph [sic] Milik for two fragments of 1 Enoch found in Cave 4."

35 See Eshel and Eshel, "New Fragments from Qumran," 154: "קטיליא [...] is the main contribution of the new fragment.[...] The appearance of this word in the new fragment 
Already in 2005, the fragment appeared in volume 3 of the authoritative The Dead Sea Scrolls Reader, with the siglum XQ8. ${ }^{36}$ In Emanuel Tov's Revised List of Texts from the Judaean Desert from 2010, it bears the revised siglum $\mathrm{X}_{2} 6$ without "Q" —and the label XpapEn ${ }^{\mathrm{a}}{ }^{37}$ The increase from 8 to 26 reflects that many of the post-2002 fragments already at that time had made it into Tov's list. The addition of the superscript "a" in the label was in order to make space for the two other Enoch fragments, see below.

Considering that this is a Kando fragment, it is noteworthy that it was the controversial antiquities dealer Ferrini who granted the Eshels permission to publish it. Already in 2004 the Eshels said there were rumours of another fragment from the same "scroll," but this never seemed to surface. This may, however, refer to 1 En. 106:19-107:1, another papyrus fragment that Schøyen acquired from Kando five years later, together with 1 En. 8:4-9:3. ${ }^{38}$ More about that later.

If authentic, this would have been the first Enoch papyrus from Qumran. It is, however, a forgery. ${ }^{39}$

\section{Intermezzo: Weston Fields's List of William Kando Fragments}

In November 2008, Weston Fields distributed a list of sixteen Dead Sea Scroll fragments owned by the Kando family to potential buyers. ${ }^{40}$ The list contained three Aramaic fragments—one from Daniel, two from Enoch, and, somewhat surprisingly, none from Tobit:

indicates that Milik's reading and reconstruction [...] [in 4Q201 iv 8] should not be accepted. L. Stuckenbruck suggested the reading קטיליא before this new fragment was discovered." Cf. Loren Stuckenbruck, "203. 4QEnochGiantsa ar," in Qumran Cave 4.XXVI: Miscellanea, Part 1, ed. Philip Alexander et al., DJD 36 (Oxford: Clarendon Press, 200o), 8-41 (18): "and [the] whole [earth] was filled with e[vil and] violence (חמסה) against the ones killed (קטיליא) [4Q201 iv 7-8]." Milik read "and the whole [earth] was filled with wickedness and violence, so that sin was brought upon it (חטי עליה[את)" (Józef T. Milik, The Books of Enoch: Aramaic Fragments of Qumrân Cave 4 [Oxford: Clarendon, 1976], 157-58).

36 Donald Parry and Emanuel Tov, eds., The Dead Sea Scrolls Reader Part 3: Parabiblical Texts (Leiden: Brill), 2005. This is still the way it is labelled in the "Qumran Non-biblical Manuscripts" module in Accordance.

37 Tov, Revised List, 110.

38 In their 2005 discussion of the Enoch fragment ("New Fragments from Qumran," 150), Eshel and Eshel interestingly show a particular interest in 1 Enoch 106-107.

39 See Davis et al., "Nine Dubious," 217-20, and Justnes and Elgvin, "Private Part."

40 The one I have seen is dated 1o November 2008. It consists of four columns with the following headings: "fragment," "length," "height," and "chapter, verse." See also Davis et al., "Nine Dubious," 198, and Justnes and Elgvin, "Private Part," 197. 


\begin{tabular}{|c|c|c|c|}
\hline No. & Chapter, verse (or name) & No. & Chapter, verse (or name) \\
\hline $\mathbf{1}$ & Dan 6:22-24 & 8 & Judg 1:10-12 \\
\hline 2 & Lev 18:27-29 & 9 & Gen $33: 18-34: 3$ \\
\hline 3 & Temple Scroll 56:6-7 & 10 & 1 En. $7: 1-4$ \\
\hline 4 & Deut 12:11-14 & 11 & Temple Scroll 54:21-55:6 \\
\hline 5 & $\begin{array}{l}\text { Judg 19:10-13 (1st column); } \\
\text { 19:23-28 (2nd column) }\end{array}$ & 12 & Exod 23:8-10 \\
\hline 6 & Paleo Leviticus Old Hebrew & 13 & Deut 9:25-10:1 \\
\hline 7 & 1 En. 8:4-9:3 & 14 & $\begin{array}{l}\text { Gen } 37: 26-38: 14 ; 37: 14-23 \\
38: 14-39: 5 \text { ( } 3 \text { fragments })\end{array}$ \\
\hline
\end{tabular}

The list provides a nice overview of some of the fragments that were soon to be bought by the Southwestern Baptists and the Schøyen Collection:

Collection Aramaic frgs Hebrew frgs

Southwestern Baptist Theological Seminary no. 1-Dan 6:22-24

(Dss F. 166) no. 2-later identified as

Lev 20:24; 18:28-30 (DSS F.162)

no. 4-Deut 12:11-14

(Dss F. 164)

no. 6-Paleo Leviticus

no. 12-Exod 23:8-10 (DSs F.161)

no. 13-Deut 9:25-10:1

(Dss F.163)

The Schøyen Collection no. $7-1$ En. 8:4-9:3

(Dss F.125)

no. $10-1$ En. $7: 1-4 / 5$

(Dss F.124)

1 En. 7:1-5 (DSS F.124, DSS F.En1) and 1 En. 106:19-107:1 (DSS F.126, Dss F.En3)

During the winter and spring of 2009, the Schøyen Collection acquired three Enoch fragments from William Kando: 1 En. 7:1-5 (= 1 En. 7:1-4 on Fields's 
list ${ }^{41}$ ), 1 En. 8:4-9:3 (which we have already discussed; on Fields's list ${ }^{42}$ ), and 1 En. 106:19-107:1 (not on the list). According to Schøyen, 1 En. 7:1-5 arrived in Norway in January and the two others in April 2009. ${ }^{43}$ Davis et al. indicate that these three fragments along with several others were bought from William Kando on demand, so to speak:

Late February and early March 2009 Schøyen approached William Kando about the possibility of acquiring fragments containing text belonging to specific books: Nehemiah, Chronicles, Ezra, 2 Kings, 1-2 Samuel, Proverbs, Qohelet, Esther, Jeremiah, and 1 Enoch. And the same year he was able to obtain MS 5426 (Nehemiah), MS 4612/10 and MS 5480 (1 Samuel), MS 4612/9 (DSS F.Jer1), MS 4612/11 (DSS F.Prov1), as well as two papyri and a parchment fragment containing text from 1 Enoch (MS 4612/6, MS 4612/8, MS 4612/12). ${ }^{44}$

With Elgvin's permission, Esther Eshel presented the new fragments of 1 En. 7:1-5 and 1 En. 106:19-107:1 at the meeting of the 5th Enoch seminar in Naples in mid-June 2009. Davila narrates:

Esther Eshel reported on two new Aramaic fragments of 1 Enoch. These are attributed to Qumran (i.e., are taken to be Dead Sea Scrolls), although they were recovered on the antiquities market and are thus unprovenanced. One is a papyrus fragment containing 1 Enoch 106:19-107:1 (from the story of the birth of Noah). The other is a parchment fragment containing 1 Enoch $7: 1-5$. Eshel thinks it is part of 4 QEnoch ${ }^{\mathrm{c}}$ ar $/ 4 \mathrm{Q}_{204}{ }^{45}$

The identification of 1 En. 7:1-5 as a fragment of 4 QEnoch ${ }^{\mathrm{c}}$ ar $\left(4 \mathrm{Q}_{204}\right)^{46}$ was wrong, but it is possible that this forgery was produced with the intention of

41 DSS F.124 is called "Enoch Aramaic" —length: $5.5 \mathrm{~cm}$; height: $3.3 \mathrm{~cm}$; chapter, verse: 7:1-4.

42 DSs F.125 is listed as "Enoch Aramaic" - length: $4.5 \mathrm{~cm}$; height: $4.5 \mathrm{~cm}$; chapter, verse: 8:4-9:3.

43 Elgvin believes all three arrived in Norway in April, in harmony with Davis et al., "Nine Dubious," 194.

44 Davis et al., "Nine Dubious," 194. See also p. 206 ("The fragment [1 En. 106:19-107:1, DSs F.126] arrived at The Schøyen Collection in 2009, a few months after a special request made by Schøyen to William Kando to locate fragments of 1 Enoch, as well as of Samuel, Nehemiah and Esther") and p. 214.

45 James R. Davila, “2 Enoch: All Your Base Are Belong to Us," PaleoJudaica.com, 20 June 2009, http://paleojudaica.blogspot.no/2009/o6/2-enoch-all-your-base-are-belong-to-us.html.

46 At that stage the Eshels still tended to identify many of the recently appeared fragments with scrolls published in DJD. The five other fragments presented in "New Fragments from Qumran" were connected with four scrolls published in DJD. The 2007 publication, 
looking like a fragment of that manuscript. In 2013 parts of 1 En. 7:1-5 were published by Michael Langlois. ${ }^{47}$ After it became clear that the three Enoch fragments were forgeries, they were removed from the Schøyen Collection and - at the eleventh hour-from the Schøyen volume. The three Enoch fragments as well as Tobit 14:3-4 are, however, dealt with in Ira Rabin's chapter "Material Analysis of the Fragments,"48 but only identified by MS-number (not by passage and Dss F.-name and number). Dan 5:13-16 (DSs F.155, Dss F.Dan1)

In August 2009, about the time when the sale of post-2002 fragments exploded, Azusa Pacific University bought five fragments (none of them on Fields's 2008 list). ${ }^{49}$ Among them was an Aramaic fragment with text from Dan 5:13-16. On 3 September the following elevated words were published on the University's website:

In its most significant holding to date-and possibly ever-Azusa Pacific University acquires five Dead Sea Scroll fragments and a collection of rare biblical antiquities.

Joining Princeton Theological Seminary and the Oriental Institute at the University of Chicago, APU becomes only the third institution of higher education to own original Dead Sea Scroll fragments. These earliest known texts of the Hebrew Bible, dating back to roughly 15 o B.C., were discovered in the caves of Qumran, east of Jerusalem, between $1947-56$. Today, many of the estimated 15,000 known fragments are held in private collections. With this acquisition, APU can study, research, and share these fragments with scholars and the public while carefully preserving the history of Scripture..$^{50}$

"A Preliminary Report on Seven New Fragments," connects all seven fragments with previously published scrolls.

Michael Langlois, "Un manuscrit araméen inédit du livre d'Hénoch et les versions anciennes de 1 Hénoch 7,4," Sem 55 (2013): 101-16.

48 Ira Rabin, "Material Analysis of the Fragments," in Gleanings from the Caves: Dead Sea Scrolls and Artefacts from The Schøyen Collection, ed. Torleif Elgvin, Kipp Davis, and Michael Langlois, LSTS 71 (London: T\&T Clark, 2016), 61-77.

49 Exod 18:6-8 (DSS F.151); Lev 10:4-7 (DSS F.152); Deut 8:2-5 (DSS F.153); Deut 27:4-6 (DSs F.154); Dan 5:13-16 (DSs F.155).

5o "Azusa Pacific University Acquires Five Dead Sea Scroll Fragments and Rare Biblical Artifacts: News Release," Azusa Pacific University, 3 September 2009, https://web.archive .org/web/20091022130226/https://www.apu.edu/media/news/release/14307/. 
The new fragments were immediately enrolled among the authentic Dead Sea Scrolls, and had also landed in the more specific context of Azusa Pacific:

"This acquisition allows us to tell the remarkable story of how humanity came to have the Bible, and how Scripture has been preserved through history," said President Jon R. Wallace, DвA. "Having these documents also reinforces APU's history and commitment to a high view of Scriptures. This is a milestone for APU, and we are deeply grateful to Legacy Ministries International for allowing us to continue Legacy's devotion to protect these ancient documents that mark the very beginnings of the written Bible."[...]

"This acquisition will set Azusa Pacific University apart from all other Christian institutions of higher education in the world," said Paul Gray, Ed.D., vice provost for graduate programs and research and dean of the University Libraries. "What better location to have available for the public to see the earliest of Scripture than in Southern California, home to millions of people."51

The fragments were linked to Lee Biondi, one of the antiquities dealers that William Kando had contacted already in 2002, to Legacy Ministries International, 52 and more indeterminably to James H. Charlesworth:

$51 \quad$ "Azusa Pacific University Acquires Five Dead Sea Scroll Fragments."

$5^{2}$ In Azusa Pacific's own magazine APU Life, the purchase of antiquities from Legacy Ministries International is interpreted in a spiritual frame of reference, see Cynndie Hoff, "Discovery and Scholarship," APU Life 23.1 (2010): 12-13 (13):

How did APU come to own these scriptural treasures? The story begins with Legacy Ministries International (LMI), an organization with a number of biblical antiquities, endeavoring to establish a permanent Bible museum. In early 2009, LMI presented an exhibition of Dead Sea Scroll fragments and biblical rarities at a church in Peoria, Arizona. Among the 20,000 visitors who attended was APU Board of Trustees Chair David Le Shana, Ph.D. "My granddaughter invited me to the exhibition, and it was a spiritually moving experience," he said. Le Shana immediately sought out LMI's Executive Director Anthony Naimo and said, "This is a powerful exhibition and fits perfectly with APU's commitment to God First and our high view of Scripture. Is there any chance we could work with LMI to bring this exhibition to APU?" That question launched a series of discussions between LMI and APU that resulted in a collaboration both institutions believe was led by God. The two organizations signed an agreement on August 5, 2009, to transfer the majority of LMI's holdings to APU's Special Collections.[...] "It was evident from the beginning that God was linking together people with a oneness of spirit and purpose," said Rev. Andy Stimer, chair of the LMI Board of Trustees. "This strategic alliance unites the strengths of two institutions 
Four of the fragments were obtained from Lee Biondi of Biondi Rare Books and Manuscripts in Venice, California. The fifth fragment came from Legacy Ministries International, a Phoenix, Arizona-based nonprofit committed to telling the story of the Bible and assembling artifacts, objects, Bibles, and documents tracing the history of Scripture.[...]

"Since their discovery, many Dead Sea Scroll fragments have been known only to their owners, and many are becoming impossible to read since they are no longer accompanied by the low humidity, thick ozone layer, and coverings that protected them for almost 2,00o years," said James H. Charlesworth, Ph.D., George L. Collord Professor of New Testament Language and Literature at Princeton Theological Seminary and director and editor of the PTs Dead Sea Scrolls Project. "Now, thanks to the president and scholars at Azusa Pacific University, these fragments have been recovered and will be scientifically protected. Each one preserves priceless data from the beginnings of Western Culture and is a unique witness to documents in the Bible of Jews and Christians." Charlesworth will be working closely with several APU faculty to publish these fragments. ${ }^{53}$

Earlier that year, on 2 February, Davila had reported on his blog that an Exodus and a Daniel fragment were for sale at Michael R. Thompson, Booksellers. Thompson advertised the Daniel fragment as follows:

29. [DEAD SEA SCROLLS]. Original fragment from Daniel, Chapter 5, Verse 13-16. Found at Qumran, on the Dead Sea, in Cave 4, some time between $195^{2}$ and 1956. The fragment itself dates between 50 BC-AD 68 (the Roman destruction of Qumran). $32 \mathrm{~mm} . \times 30 \mathrm{~mm}$., written in Hebrew on brown animal hide. Preserved between glass, and enclosed in cloth chemise, in full black morocco clamshell slipcase. \$275,000.

Includes the verse translated in English as: "Art thou that Daniel, which art of the children of the captivity of Iudah ..."54

completely committed to the primacy of Scripture. Together, we can make these treasures accessible to scholars and believers on a grand scale."

54 James R. Davila, "Dead Sea Scrolls for Sale," PaleoJudaica.com, 2 February 2009, http:// paleojudaica.blogspot.no/2009/o2/dead-sea-scrolls-fragments-for-sale-by.html. Davila was quoting from Thompson's blog, but this post has since been removed. 
In a follow-up two short weeks later, some quite disturbing details were revealed:

When asked to see the pieces, Thompson reveals that he's been holding the coveted religious documents in his jacket pocket.

"You put it in a big fancy case, and it pretty much screams out that 'This is worth something," said Thompson, figuring the items would be harder to steal when they're close to his chest. ${ }^{55}$

Colourful bits like these seem to have been left out of Azusa Pacific's more official narrative of the acquisition of the fragments (cf. above). Journalist Joy Juedes celebrates in particular professor Robert Duke's central role:

Duke has helped bring the scrolls to Azusa Pacific University.[...] [he] spent most of the summer confirming the authenticity of the five scroll fragments the university recently acquired.

The scrolls are the earliest known texts of the Hebrew Bible, dating back to roughly 15 о B.c. They were discovered in caves at Qumran, east of Jerusalem, between $1947-56$.[...]

"Ninety percent are in Israel or Jordan, and then there are these fragments that are in private collections," Duke said.

Duke said it is difficult to get ancient artifacts out of their countries of origin because of international rules and a recent antiquity fraud scandal at the Getty Museum.

$[\ldots]$

Duke said when he first saw digital photos of the fragments, he was struck by how genuine they looked.

"I spent a few months poring over photos, going to the seller to make sure they were authentic," he said.

"Some of it is just looking at lettering - they look like what other scrolls look like that came out of Qumran or other caves," he said.

The seller also provided carbon dating information, which helps verify age, he said.

"By looking at it and comparing with other fragments it was pretty clear we were handling the real material," he said.

55 James R. Davila, "More on the Dead Sea Scroll Fragments," PaleoJudaica.com, 15 February 2009, http://paleojudaica.blogspot.no/2009/o2/more-on-dead-sea-scrollfragments-for.html. 
Azusa's special collections staff is in charge of handling, preservation, and access to the fragments. The school also checked to make sure the fragments were not illegally owned at some point. ${ }^{56}$

The notorious vagueness and the implicitly apologetic tone that characterises so much of the reports on the post-2002 fragments are noteworthy also in this piece. It is important for Duke to communicate that these fragments are the real thing: they look like Dead Sea Scroll fragments, behave like Dead Sea Scrolls, are treated as Dead Sea Scrolls—and even come with carbon 14 dating. They are not forgeries, and they have not been smuggled.

When Daniel Estrin writes about the new fragments in 2013, an important detail is added to the story-William Kando: "Kando told The Associated Press he was the source of all the fragments." ${ }^{n 7}$ The late mention of William Kando in this part of the story is peculiar, and I am honestly not sure precisely what to make of it. 58

Despite the hype — still ongoing 59 — it is already well established even before the official publication of the Azusa collection that the two Deuteronomy fragments Deut 8:2-5 (DSs F.153) and Deut 27:4-6 (DSs F.154) are forgeries. ${ }^{60}$ The Daniel fragment under scrutiny here contains most of the features that we have learned to expect from these newer fragments: the handwriting is imitative and hesitant, and the letters inconsistent. Several of them are modified to

$5^{6} \quad$ Joy Juedes, "Yucaipan brings scrolls to Azusa Pacific," Redlands Daily Facts, 1 October 2009.

57 Estrin, "Dead Sea Scroll Fragments."

$5^{8}$ Cf. also Owen Jarus, "28 Dead Sea Scroll Fragments Sold in the U.S," cBs News, 3 April 2017, https://www.cbsnews.com/news/28-dead-sea-scroll-fragments-sold-in-the-u-s/:

Before Azusa Pacific University purchased the scroll fragments, the university received assurances from William Kando that the Kando family had owned those fragments in the past, Duke said.

59 See "Publication of Azusa Pacific University's Dead Sea Scrolls to Enhance Biblical Scholarship," News release, 17 May 2017, https://www.apu.edu/media/news/release/25415/.

6o Concerning DSS F.153, see Eibert J. C. Tigchelaar, "Dittography and Copying Lines in the Dead Sea Scrolls: Considering George Brooke's Proposal about 1QpHab 7:1-2," in Is There a Text in This Cave? Studies in the Textuality of the Dead Sea Scrolls in Honour of George J. Brooke, ed. Ariel Feldman, Maria Cioată, and Charlotte Hempel, sTDJ 119 (Leiden: Brill, 2017), 293-307 (297, n. 14): "I surmise that DSS.F133 [sic = DSS F.153] (APU 3) is a modern forgery, imitating 4Q30 5, even up to a similarity of the shapes of some letters", and Davis, "Caves of Dispute," 256-58. Concerning Dss F.154, see Årstein Justnes, "Forfalskninger av dødehavsruller: Om mer enn 70 nye fragmenter — og historien om ett av dem (DSs F.154; 5 Mos 27,4-6) [Faking the Dead Sea Scrolls: On More than 70 New Fragments—and the Story about One of Them (DSs F.154; Deut 27:4-6)]," Teologisk Tidsskrift 6.1 (2017): 70-83. Tigchelaar, "Beautiful Bookhands," comments on both fragments. 
fit the damage pattern on the surface of the fragment. This is hardly a fragment from a scroll, but more likely a fragment inscribed in modern times.

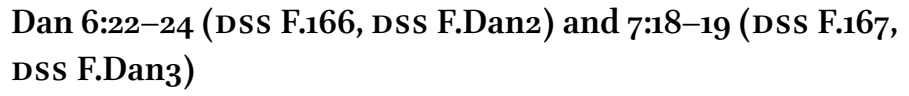

On the nineteenth of January 2010, the Southwestern Baptist Theological Seminary (swBTs) acquired two Aramaic papyri fragments, Dan 6:22-24 (21-23) and Dan 7:18-19, along with two Hebrew fragments, Exod 23:8-10 (DSS F.161) and Lev 20:24; 18:28-30 (DSS F.162), from William Kando. ${ }^{61}$ As the reader may remember, all of these, with the exception of Dan 7:18-19, were on Fields's 2008 list. ${ }^{62}$

The acquisition of the swBts fragments is documented in Armour Patterson's book Much Clean Paper for Little Dirty Paper. Patterson's story basically starts with a failed attempt to get Kando's famous scroll jar out of Israel, and culminates in two major incidents on the fourth of July 2009:

Knowing the prospect to be an unlikely one, Dorothy [Patterson, wife of former Southwestern Baptist Theological Seminary president Paige Patterson] nevertheless made an attempt to buy Kando's jar in July of 2007. As she had suspected, though, she learned that there still was no legal way to get it out of Israel and gave up on any idea of obtaining artifacts with any connection to the Dead Sea Scrolls. Two years later, however, at the new Kando Store in Bethlehem, everything changed. The stakes in the long-running pursuit of antiquities were most unexpectedly raised with an offer that none of us could have seen coming. While in the store on July 4, 2009, with a swBTs donor study tour group, [...] William Kando approached Dorothy about the prospect of purchasing fragments of the Dead Sea Scrolls. ${ }^{63}$

On the evening of July 4, 2009, the Pattersons, their small tour group, and swвтs archaeologist Steve Ortiz met at the American Colony Hotel in Jerusalem with Dead Sea Scrolls specialists, Hanan and Esti Eshel. There

\footnotetext{
61 Armour Patterson, Much Clean Paper for Little Dirty Paper: The Dead Sea Scrolls and the Texas Musâwama (Collierville, TN: Innovo Publishing, 2012), 31-32.

62 DSs F.166 is called "Daniel Papyrus" on Fields's list. The list also provides the following information about this fragment: length: $5.5 \mathrm{~cm}$; height: $2.5 \mathrm{~cm}$; chapter, verse: 6:22-24.

63 Patterson, Much Clean Paper, 28.
} 
they compared the lists of fragments and photographs given to Dorothy by William Kando with the list in the hands of the archaeologists in Jerusalem. The list in the hands of the Eshels matched perfectly the list the Pattersons had been provided by William Kando, a crucial first step in authenticating the fragments. Weston W. Fields also verified the affirmation of the Pattersons that the Kando family could have genuine fragments and that they were trustworthy. ${ }^{64}$

On this noteworthy date, at this noteworthy place, with the support of prominent scholars Hanan and Esther Eshel, and the leader of the Dead Sea Scrolls Foundation, ${ }^{65}$ not only the fragments, but also William Kando's business, are authenticated. There is reason to assume that the list mentioned in the quote is identical with the list mentioned above. At this point the scene changes in Patterson's narrative:

From this point forward, the negotiations moved to Zurich, Switzerland, where the scroll fragments had been kept for decades in a vault at the uBs Bank. "Old Man Kando," as I affectionately remember him, being a shrewd businessman, had known that the time for taking any artifacts out of the country was short. He thus took fragments of the scrolls in his possession out of the country before the enactment of laws that would have prevented any such movement. Though one could make some educated guesses, the path the scroll fragments took is not important, but what is relevant here is that their final destination was the unparalleled security of the Swiss bank in Zurich. ${ }^{66}$

As in Schøyen's provenance lists, "Old Man Kando" is the key figure also in Patterson's fragmented provenance narrative, just as is Zurich, Switzerland:

There were five meetings at the UBs Bank in Zurich between October 6, 2009, and May 18, 2011, in which William Kando and Dorothy Patterson were the principals. D. Cipriano, the uBs Bank officer assigned to William

64 Patterson, Much Clean Paper, 30.

65 Also elsewhere in the book, Fields's essential role as facilitator is honoured: "Weston W. Fields, head of the Dead Sea Scrolls Foundation in Jerusalem, a man who knows business, the Scriptures, Middle Eastern lands and cultures, and the history of the Dead Sea Scrolls, would prove not only valuable but essential in maximizing the success of the project. Others would also become patrons of the Dead Sea Scrolls project" (Patterson, Much Clean Paper, 28).

66 Patterson, Much Clean Paper, 3 o. 
Kando, also attended the meetings in a neutral and procedural role. Formalities of paperwork, specific counsel, and the removal of scroll fragments from the vault were handled by Cipriano. When agreement upon price had been reached and a check was produced, or sometimes when agreement was close, the bank officer assisted with formalities. ${ }^{67}$

In between Patterson's long descriptions of the tough, but at the same time profound and respectful negotiations between Dorothy and William, contours of an alternative provenance narrative emerge:

Of the five meetings in Zurich between Dorothy Patterson and William Kando, neither the first [...], nor the last[...], resulted in any acquisitions. $[\ldots]$. The last meeting in Zurich, though resulting in no acquisition, was significant for two reasons. First, as the Pattersons already knew, more fragments were available. Second, and more important, one of the reasons for that availability was clarified. As suggested previously, no one ever knew for sure all that the Kandos had, and certainly no one knew all that the family knew. Important fragments of the scrolls had long been missing from the primary museum collections, their whereabouts unknown. The Kandos knew which private collectors had bought some of those crucial fragments in the early days of the recovery of the scrolls from the desert caves. William Kando had begun to purchase fragments from the private collectors who had originally made purchases either from William's father or from someone else known to him. Thus, more was available than the Pattersons had known when negotiations began. ${ }^{68}$

Patterson here offers a much-needed explanation of the growing number of fragments: after the negotiations began, Kando had allegedly started to purchase fragments from private collectors.

At their second meeting in Zurich, Dorothy Patterson purchased what later turned out to be two Daniel fragments, ${ }^{69}$ along with two other fragments:

At the end of long hours of increasingly intense negotiation, Dorothy Patterson, with the generous financial gifts of swBTs donors, was able to

67 Patterson, Much Clean Paper, 31.

68 Patterson, Much Clean Paper, 32-33.

69 In the exhibition catalogue Dead Sea Scrolls and the Bible from 2012 the Daniel fragments are labelled fragments 1 and 2. See Gary Loveless and Stephanie Loveless, Dead Sea Scrolls and the Bible: Ancient Artifacts, Timeless Treasures: Exhibition Catalogue (Fort Worth, TX: Southwestern Baptist Theological Seminary, 2012), 91. 
purchase and take back to Texas three fragments: Daniel 6:22-24 (which was later discovered to include Daniel 7:18-19), Leviticus 18:27-29, and Exodus 23:8-10.70

Six months later, still according to Armour Patterson, at a third meeting in Zurich 3 September 2010, Dorothy Patterson purchased two more fragments, Deut 12:11-14 and 9:25-10:1, and received Ps 22:4-13 as a gift from William Kando. The crowning event, three months later, led to a purchase of a fragment that had been known even before 2002, and is considered by most scholars as authentic — the famous Paleo-Leviticus fragment:

The greatest acquisition, both in size and in value, came nearly three months later after much hard work and generous gifts by Southwestern Seminary donors. At the close of negotiations on Monday, November 29, 2010, Dorothy Patterson and Candi Finch left the u Bs Bank in Zurich for the flight home to Fort Worth with the Paleo-Leviticus fragment containing portions of Leviticus 21:7-12 and 22:21-27. Interestingly, we have learned that this fragment was originally sold by Kando, William's father, in 1967 to Professor Georges Roux[...]. William Kando repurchased the piece and obtained with it the old cigar box in which it was originally carried and sold. Upon the purchase of the fragment, he was kind enough to gift the original cigar box to swвтs. ${ }^{71}$

Amour Patterson is a writer of fiction, and parts of Much Clean Paper for Little Dirty Paper read almost like a hagiography of the elder Kando and his son William. This is definitely also a tendency in Fields's Lanier Lecture from 2011, where he tries to create a space for the Psalm 22 fragment in the official story of the Dead Sea Scrolls. Estrin's piece from 2013 definitely modifies this image. He reported there that Dorothy Patterson had to pay a higher prize for the Leviticus 18 and 20 fragment because it contained material about sexual immorality:

"That scroll fragment includes passages from chapters 18 and 20 concerning the laws of sexual morality, and carried a special price tag because of the text's significance," said Bruce McCoy of the Seminary. "The particular

$70 \quad$ Patterson, Much Clean Paper, 33.

71 Patterson, Much Clean Paper, 35. 
passage is a timeless truth from God's word to the global culture today," said McCoy. ${ }^{72}$

I have earlier suggested that this fragment might have been produced for American evangelicals. ${ }^{73}$ As far as the Aramaic Daniel fragments are concerned, it is natural to group them among the other post-2002 forgeries: the hand in both pieces is hesitant and inconsistent, and some of the letters are adjusted along the edges of the fragments. The line spacing also differs between them.

\section{$8 \quad$ Concluding Remarks}

We academics must help protect the objects we study. Some of my colleagues believe that scholarship comes first, or say that texts have no guilt, so we should be faithful to them. They publish what emerges from the market. I disagree. To publish papyri with suspicious - if not illegalprovenance is unethical. It lends a new identity to those artefacts and feeds the illicit market.[...] Those who study papyri must exercise due diligence before publishing anything, and academics should exercise an active role in educating collectors and keeping an eye on the market. Would you knowingly buy a stolen bike? Why would you buy—or publish—a stolen manuscript?74

Looking back, it is abundantly clear that it was wrong to purchase the Aramaic fragments under scrutiny in this article without performing due diligence. As this study has shown, the pedigrees, the lists of previous owners, and the stories by which the fragments were marketed cannot be trusted for any of the fragments.

Despite the fundamentally problematic nature of all the post-2002 fragments, most Qumran scholars that have worked on them have taken the essence of the dealers' and collectors' claims, i.e. that the fragments came from Qumran, as their point of departure, honoured it, and often to a large extent confirmed it in their own ways. Some scholars even took it upon themselves to

\footnotetext{
72 Estrin, "Dead Sea Scroll fragments."

73 Quoted in Nina Burleigh, "Newly Discovered Dead Sea Scrolls are Skillfully Crafted Fakes, Experts Suspect," Newsweek, 18 October 2016, http://www.newsweek.com/2016/10/28/ dead-sea-scroll-fragments-fake-experts-suspect-511224.html, and Candida Moss and Joel Baden, Bible Nation: The United States of Hobby Lobby (New Jersey: Princeton University Press, 2017), 34-35.

Mazza, "The Illegal Papyrus Trade."
} 
improve or substantiate Kando's provenance narratives, either with the aid of physical testing or by writing the new fragments into the official story of the Dead Sea Scrolls. This definitely helped to drive up the prices of the fragments and created incentives for the production of forgeries. ${ }^{75}$

\section{Bibliography}

"Azusa Pacific University Acquires Five Dead Sea Scroll Fragments and Rare Biblical Artifacts: News Release." Azusa Pacific University, 3 September 2009, https://web .archive.org/web/20091022130226/https://www.apu.edu/media/news/release/ $14307 /$.

"Azusa Pacific's Dead Sea Scrolls and Biblical Artifacts Exhibition Opens May 21: News Release." Azusa Pacific University, 11 May 2010, https://www.apu.edu/media/news/ release $/ 15664 /$.

Biondi, Lee. From the Dead Sea Scrolls to the Forbidden Book: A Brief History of the Bible Told through Ancient Manuscripts \& Early Printed Bibles. Dallas, TX: [Publisher unknown], 2004.

Brooke, George J. "Dead Sea Scrolls Scholarship in the United Kingdom." Pages 449-86 in The Dead Sea Scrolls in Scholarly Perspective: A History of Research. Edited by Devorah Dimant. STDJ 99. Leiden: Brill, 2012.

Burleigh, Nina. "Newly Discovered Dead Sea Scrolls are Skillfully Crafted Fakes, Experts Suspect." Newsweek, 18 October 2016, http://www.newsweek.com/2016/10/28/dead -sea-scroll-fragments-fake-experts-suspect-511224.html.

Charlesworth, James H. "The Discovery of an Unknown Dead Sea Scroll: The Original Text of Deuteronomy 27?" OWU Magazine, Summer 2012, https://web.archive .org/web/20140226221353/http://blogs.owu.edu/magazine/the-discovery-of-an -unknown-dead-sea-scroll-the-original-text-of-deuteronomy-27/.

Charlesworth, James H. "What Is a Variant? Announcing a Dead Sea Scrolls Fragment of Deuteronomy." Maarav 16 (2009): 201-12.

Cook, Edward M. "A Lost Scrap of Tobit from the Schoyen Collection." Ralph the Sacred River, 9 December 2005, http://ralphriver.blogspot.dk/2005/12/lost-scrap-of-tobit -from-schoyen.html.

Davila, James R. "2 Enoch: All Your Base Are Belong to Us." PaleoJudaica.com, 2o June 2009, http://paleojudaica.blogspot.no/2009/o6/2-enoch-all-your-base-are -belong-to-us.html.

75 Thanks to Ludvik A. Kjeldsberg, Kristine Toft Rosland, and Line Reichelt Føreland for critical response on an earlier draft of this article. 
Davila, James R. “Dead Sea Scrolls for Sale." PaleoJudaica.com, 2 February 2009, http:// paleojudaica.blogspot.no/2009/02/dead-sea-scrolls-fragments-for-sale-by.html.

Davila, James R. "More 1 Enoch from the Qumran Library." PaleoJudaica.com, 10 October 2004, http://paleojudaica.blogspot.no/2004_10_10_archive.html\#10978 2863646134864 .

Davila, James R. "More on the Dead Sea Scroll Fragments." PaleoJudaica.com, 15 February 2009, http://paleojudaica.blogspot.no/2009/02/more-on-dead-sea -scroll-fragments-for.html.

Davila, James R. "News on the New 1 Enoch Fragment." PaleoJudaica.com, 22 November 2004, http://paleojudaica.blogspot.no/2004/11/news-on-new-1-enoch -fragment-yesterday.html.

Davis, Kipp. "Caves of Dispute: Patterns of Correspondence and Suspicion in the Post2002 'Dead Sea Scrolls' Fragments.” DSD 24 (2017): 229-70.

Davis, Kipp, Ira Rabin, Ines Feldman, Myriam Krutzsch, Hasia Rimon, Årstein Justnes, Torleif Elgvin, and Michael Langlois. "Nine Dubious 'Dead Sea Scrolls' Fragments from the Twenty-First Century." DSD 24 (2017): 189-228.

Dimant, Devorah. "Tobit and the Qumran Aramaic Texts." Pages 173-91 in From Enoch to Tobit: Collected Studies in Ancient Jewish Literature. Edited by Devorah Dimant. FAT 114. Tübingen: Mohr Siebeck, 2017.

Elgvin, Torleif, Kipp Davis, and Michael Langlois, eds. Gleanings from the Caves: Dead Sea Scrolls and Artefacts from The Schøyen Collection. LSTS 71. London: T\&T Clark, 2016.

Eshel, Esther, and Hanan Eshel. "A New Fragment of the Book of the Watchers from Qumran (XQpapEnoch).” Tarbiz 73 (2004): 171-79 [Hebrew]; v [English Abstract].

Eshel, Esther, and Hanan Eshel. "A Preliminary Report on Seven New Fragments from Qumran." Meghillot 5-6 (2007): 271-78.

Eshel, Esther, and Hanan Eshel. "New Fragments from Qumran: 4QGen', 4QIsab, 4Q226, 8QGen, and XQpapEnoch." DSD 12 (2005): 134-57.

Eshel, Hanan. "Gleaning of Scrolls from the Judean Desert." Pages 49-87 in The Dead Sea Scrolls: Texts and Context. Edited by Charlotte Hempel. STDJ 9o. Leiden: Brill, 2010.

Estrin, Daniel. "Dead Sea Scroll fragments to hit the auction block." Times of Israel, 25 May 2013, http://www.timesofisrael.com/dead-sea-scroll-fragments-to-hit-the -auction-block/.

Fields, Weston W. "Dead Sea Scrolls: Significance of the Latest Developments." The Lanier Library Lecture Series, 16 April 2011, https://www.youtube.com/watch ?v=cOcNhHsGKu4. The Q \& A session, https://www.youtube.com/watch?v=9qg LWNRtL5Q.

Flint, Peter. The Dead Sea Scrolls. Nashville: Abingdon, 2013. 
Fonn, Geir Ove. "Dødehavsruller er lukrativ svindelindustri." Vårt Land, 16 August 2017, https://www.vl.no/nyhet/dodehavsruller-er-lukrativ-svindelindustri -1.1013905? paywall=true16-17.

Hallermayer, Michaela, and Torleif Elgvin. "Schøyen ms. 5234: Ein neues TobitFragment vom Toten Meer." RevQ 22/87 (2006): 451-61.

Hoff, Cynndie. "Discovery and Scholarship." APU Life 23.1 (2010): 12-13.

Holm, Tawny L. "Memories of Sennacherib in Aramaic Tradition." Pages 295-323 in Sennacherib at the Gates of Jerusalem (701 B.C.E.): Story, History and Historiography. Edited by Isaac Kalimi and Seth Richardson. CHANE 71. Leiden: Brill, 2014.

Jarus, Owen. “28 Dead Sea Scroll Fragments Sold in the U.S." cвs News, 3 April 2017, https://www.cbsnews.com/news/28-dead-sea-scroll-fragments-sold-in-the-u-s/.

Juedes, Joy. "Yucaipan brings scrolls to Azusa Pacific." Redlands Daily Facts, 1 October 2009.

Justnes, Årstein. “Forfalskninger av dødehavsruller: Om mer enn 70 nye fragmenterog historien om ett av dem (DSs F.154; 5 Mos 27,4-6) [Faking the Dead Sea Scrolls: On More than 70 New Fragments - and the Story about One of Them (DSs F.154; Deut 27:4-6)]." Teologisk Tidsskrift 6.1 (2017): 70-83.

Justnes, Årstein. Review of Dead Sea Scrolls Fragments in the Museum Collection, ed. Emanuel Tov, Kipp Davis, and Robert Duke. DSD (2017): 310-12, http://booksandjour nals.brillonline.com/content/journals/10.1163/15685179-12341432? showFullText=pdf. Justnes, Årstein, and Ludvik A. Kjeldsberg. "Post-2002 Dead Sea Scrolls-like Fragments Online: A [Really Exhausting] Guide for the Perplexed." The Lying Pen of Scribes: Manuscript Forgeries and Counterfeiting Scripture in the Twenty-First Century 26 June 2018, https://lyingpen.com/.

Justnes, Årstein, and Ludvik A. Kjeldsberg. “The Post-2002 Dead Sea Scrolls Fragments: A Tentative Timeline of Acquisitions." The Lying Pen of Scribes: Manuscript Forgeries and Counterfeiting Scripture in the Twenty-First Century, 7 June 2018, https://lying pen.com/.

Justnes, Årstein, and Josephine M. Rasmussen. "Soli Deo Gloria? The Scholars, the Market, and the Dubious Post-2002 Dead Sea Scrolls-like Fragments." The Bible and Interpretation, 11 November 2017, http://www.bibleinterp.com/.

Justnes, Årstein, and Torleif Elgvin. "A Private Part of Enoch: A Forged Fragment of 1 Enoch 8:4-9:3." Pages 195-203 in Wisdom Poured Out Like Water: Studies on Jewish and Christian Antiquity in Honor of Gabriele Boccaccini. Edited by J. Harold Ellens, Isaac W. Oliver, Jason von Ehrenkrook, James Waddel, and Jason M. Zurawski. DCLS 38. Berlin and Boston: Walter de Gruyter, 2018.

Langlois, Michael. "Nine Dubious 'Dead Sea Scrolls' Fragments from the TwentyFirst Century." The Blog of Michael Langlois, 8 October 2017, https://michael langlois.fr/en/publications/neuf-fragments-de-manuscrits-de-la-mer-morte -douteux-apparus-au-xxie-siecle. 
Langlois, Michael. "Un manuscrit araméen inédit du livre d'Hénoch et les versions anciennes de 1 Hénoch 7,4." Sem 55 (2013): 101-16.

Loveless, Gary, and Stephanie Loveless. Dead Sea Scrolls and the Bible:Ancient Artifacts, Timeless Treasures: Exhibition Catalogue. Fort Worth: Southwestern Baptist Theological Seminary, 2012.

Mazza, Roberta. "The Illegal Papyrus Trade and What Scholars Can Do to Stop It." Hyperallergic, 1 March 2018, https://hyperallergic.com/429653/the-illegal-papyrus -trade-and-what-scholars-can-do-to-stop-it/.

Milik, Józef T., with Matthew Black. The Books of Enoch: Aramaic Fragments from Qumran Cave 4. Oxford: Clarendon, 1976.

Mizzi, Dennis, and Jodi Magness. "Provenace vs. Authenticity. An Archeological Perspective on the Post-2002 'Dead Sea Scrolls-Like' Fragments." DSD 26 (2019): 135-69.

Moss, Candida, and Joel Baden. Bible Nation: The United States of Hobby Lobby. New Jersey: Princeton University Press, 2017.

Parry, Donald, and Emanuel Tov, eds. The Dead Sea Scrolls Reader Part 3: Parabiblical Texts. Leiden: Brill, 2005.

Patterson, Armour. Much Clean Paper for Little Dirty Paper: The Dead Sea Scrolls and the Texas Musâwama. Collierville, TN: Innovo Publishing, 2012.

Puech, Émile. "Un nouveau fragment 7 a de $4 \mathrm{QGn}-\mathrm{Ex}^{\mathrm{a}}=4 \mathrm{QGen}-\mathrm{Ex} 1$ et quelques nouvelles lectures et identifications du manuscrit 4Q1." RevQ 25/97 (2011): 103-11.

Rabin, Ira. "Material Analysis of the Fragments." Pages 61-77 in Gleanings from the Caves: Dead Sea Scrolls and Artefacts from The Schøyen Collection. Edited by Torleif Elgvin, Kipp Davis, and Michael Langlois. LSTS 71. London: T\&T Clark, 2016.

Schøyen, Martin. “Acquisition and Ownership History: A Personal Reflection." Pages 27-31 in Gleanings from the Caves: Dead Sea Scrolls and Artefacts from The Schøyen Collection. Edited by Torleif Elgvin, Kipp Davis, and Michael Langlois. LSTs 71. London: T\&T Clark, 2016.

Stuckenbruck, Loren. “203. 4QEnochGiants"a ar." Pages 8-41 in Qumran Cave 4.XXVI: Miscellanea, Part 1 . Edited by Stephen Pfann and Philip Alexander. DJD 36. Oxford: Clarendon, 2000.

Stuckenbruck, Loren, and Stuart Weeks. "Tobit." Pages 237-6o in T\&T Clark Companion to the Septuagint. Edited by James K. Aitken. London: Bloomsbury, 2015.

Tervanotko, Hanna. "You Shall See': Rebekah's Farewell Address in 4Q364 3 ii 1-6." Pages 413-26 in The Hebrew Bible in Light of the Dead Sea Scrolls. Edited by Nóra Dávid, Armin Lange, Kristin De Troyer, and Shani Tzoref. FrLANT 239. Göttingen: Vandenhoeck \& Ruprecht, 2012.

Tigchelaar, Eibert J. C. "Beautiful Bookhands and Careless Characters: An Alternative Approach to the Dead Sea Scrolls." The 8th Annual Rabbi Tann Memorial 
Lecture, University of Birmingham, 24 January 2018, https:/www.youtube.com/ watch?time_continue $=5 \& \mathrm{v}=$ thB2 2 H1kwtU.

Tigchelaar, Eibert J. C. "Dittography and Copying Lines in the Dead Sea Scrolls: Considering George Brooke's Proposal about 1QpHab 7:1-2." Pages 293-307 in Is There a Text in This Cave? Studies in the Textuality of the Dead Sea Scrolls in Honour of George J. Brooke. Edited by Ariel Feldman, Maria Cioată, and Charlotte Hempel. STDJ 119. Leiden: Brill, 2017.

Tov, Emanuel. "Introduction, Text Editions, the Collection of the Museum of the Bible, Textual and Orthographic Character, Relation to Other Fragments from the Judaean Desert." Pages 3-18 in Dead Sea Scrolls Fragments in the Museum Collection. Edited by Emanuel Tov, Kipp Davis, and Robert Duke. Publications of Museum of the Bible 1. Leiden: Brill, 2016.

Tov, Emanuel. “New Fragments of Amos.” DSD 21 (2014): 3-13, http://www.emanueltov .info/docs/varia/256.amos-almost-final.pdf?v=1.o.

Tov, Emanuel. Revised List of Texts from the Judaean Desert. Leiden: Brill, 2010.

Tov, Emanuel, Kipp Davis, and Robert Duke, eds. Dead Sea Scrolls Fragments in the Museum Collection. Publications of Museum of the Bible 1. Leiden: Brill, 2016.

Weeks, Stuart. "Restoring the Greek Tobit." JSJ 44 (2013): 1-15.

Zahn, Molly M. Review of Gleanings from the Caves: Dead Sea Scrolls and Artefacts from the Schøyen Collection, ed. Torleif Elgvin, Kipp Davis, and Michael Langlois. DSD 24 (2017): 307-9, http://booksandjournals.brillonline.com/content/journals/ $10.1163 / 15685179-12341431$. 